\title{
Digital surface models and the landscape: Interaction between Bedrock and Glacial geology in the Ullapool area
}

\author{
K.M. Goodenough, M. Krabbendam, T. Bradwell, A. Finlayson and A.G.Leslie \\ British Geological Survey, Murchison House, West Mains Road, Edinburgh EH9 \\ 3LA
}

Corresponding author: kmgo@bgs.ac.uk

\begin{abstract}
The front cover image for this volume is a hill-shaded digital surface model (DSM) of the Ullapool area, created using NEXTMap Britain elevation data from Intermap Technologies. This is a classic area for bedrock geology, transected by the Moine Thrust Zone, and in recent years has also been studied in detail for its glacial history. Perhaps equally important, this is one of Scotland's most iconic landscapes. The geology of the area comprises a number of distinct sequences, each of which has a characteristic landscape expression as illustrated by the DSM. This paper considers the influence of the bedrock geology on the glacial geomorphology, and shows that the interplay of the two has led to the development of the different landscape elements of this spectacular area.
\end{abstract}

\section{Introduction}

This paper is based on the front cover image for this volume, which is a hill-shaded digital surface model (DSM) of the area around Ullapool in the North West Highlands 
of Scotland (Figure 1). The DSM was created using NEXTMap Britain elevation data from Intermap Technologies, and has been processed to produce a hill-shaded image with apparent illumination from the north-west. The data were obtained by airborne Inferometric Synthetic Aperture radar, flown at a height of $6000-9000 \mathrm{~m}$. The horizontal resolution is $2-5 \mathrm{~m}$, and the elevation resolution is about $1 \mathrm{~m}$. NEXTMap digital surface models cover the entire landmass of Britain and the whole dataset has been purchased by NERC. The DSM coverage allows unprecedented opportunities for interpreting the landscape, since they have a far higher resolution than most widely available satellite imagery, and can provide a broader overview than stereographic aerial photos. The only major problem in areas of high relief is that some steep slopes fall in the shadow of the radar swath and are not imaged, for example the north-west face of Ben Mòr Coigach.

A team of staff from the British Geological Survey has been carrying out surveys of the bedrock geology and glacial deposits in the North West Highlands since 2001. Part of the front cover image lies within the Ullapool map sheet (Scotland sheet 101E), and the bedrock version of this sheet has recently been published (British Geological Survey, 2008). Because bedrock geologists and geomorphologists have worked in the same area at the same time, we have recognised that variations in solid geology have a significant influence on the glacial deposits and landforms that were developed during the Pleistocene. This paper explores the interplay between the different aspects of geology, particularly those aspects that can be determined from the DSM. 


\section{Bedrock geology of the Ullapool area}

The town of Ullapool lies on the Moine Thrust Zone (Figure 2), a major geological structure that extends through the North West Highlands from Loch Eriboll in the north to the Isle of Skye in the south (Peach et al., 1907; Elliott and Johnson, 1980), and which represents the front of the Silurian-age Caledonian orogenic belt. To the west of the Moine Thrust Zone lies the largely undeformed Foreland (Park et al., 2002), consisting of Precambrian basement (the Lewisian Gneiss Complex) overlain by Neoproterozoic sedimentary rocks (the Stoer and Torridon groups, formerly considered as the Torridonian Supergroup; Stewart, 2002, Kinnaird et al., 2007) and a Cambro-Ordovician sedimentary succession (the Ardvreck and Durness groups). Parts of this tripartite succession also occur in the Moine Thrust Zone, where the units are deformed by thrusting and folding related to the Caledonian orogeny. The Moine Thrust Zone is bounded by the lowermost (and westernmost) Sole Thrust, and the uppermost Moine Thrust. East of the Moine Thrust lie Neoproterozoic metasedimentary rocks of the Moine Supergroup, now considered as lateral equivalents of the Torridon Group (Krabbendam et al., 2008a) which were brought into their current position by movement on the Moine Thrust around 430 Ma (Freeman et al., 1998). In the area around Ullapool, south of Knockan Crag (Figure 2), the Moine Thrust Zone is relatively narrow or in some places represented only by the Moine Thrust itself (Peach et al. 1907; British Geological Survey, 2008). The exceptions to this are the small culminations at Langwell, Loch Achall, Ullapool and Dundonnell (Elliott and Johnson, 1980). The northerly three of these each contain thrust sheets of unusually homogeneous, syenitic Lewisian gneiss (termed the Ullapool Gneiss; British Geological Survey, 2008). In the Achall and Ullapool culminations, the gneiss 
is overlain by red sandstones that are thought to correlate with the Torridon Group these are well-exposed at Corry Point south-east of Ullapool.

North of Knockan Crag, and largely beyond the area covered by this paper, the Moine Thrust Zone widens into the famous Assynt Culmination (Elliott and Johnson, 1980; British Geological Survey, 2007). Associated with this broad window through the thrust zone are a variety of alkaline igneous intrusions (Parsons, 1999) which include both the major plutons of Loch Ailsh and Loch Borralan and a host of minor intrusions. Some of these minor intrusions extend along the Moine Thrust Zone as far south as Ullapool (Sabine, 1953).

West of the Moine Thrust Zone, gently south-easterly-dipping Torridon Group sandstones form the hills of Coigach, the coastal peninsulas south of Loch Broom, and the peaks of An Teallach and the Fisherfield Forest. The more easterly of these peaks, such as Beinn a' Chlaidheimh, are capped by white-weathering quartz arenites of the Ardvreck Group (Geological Survey, 1908). The western hills and slopes of the Fisherfield Forest are underlain by gneisses of the Lewisian Gneiss Complex, with a distinctive rough topography.

East of the Moine Thrust in the Ullapool area lies the psammite-dominated Morar Group, the lowermost group of the Moine Supergroup (Holdsworth et al., 1994), which forms the mountain massifs of Beinn Dearg, Seana Bhraigh and the Fannichs. Immediately above the Moine Thrust itself, the Morar Group rocks are strongly mylonitic (Elliott and Johnson, 1980) and the mylonites pass upward into thinlylayered, ‘flaggy’ psammites, the layering being equivalent to thinned original bedding. These layers generally dip gently south-eastwards and tend to increase in thickness eastward away from the Moine Thrust, so that near Beinn Dearg the psammites commonly form beds up to $5 \mathrm{~m}$ thick. A number of semipelitic to pelitic 
units occur within the Morar Group, the thickest of which is the Vaich Pelite, east of Beinn Dearg and Seana Braigh. At the western end of the Fannich hills, the Sgurr Beag Thrust underlies an outlier of gneissose semipelite that belongs to the Glenfinnan Group, the middle group of the Moine Supergroup.

Between Gruinard Bay and Loch Ewe are exposures of a narrow strip of Triassic sandstone overlain by Jurassic limestone and mudstone (Johnstone \& Mykura, 1989). These form part of the Minch Basin, brought down by normal fault movements along the Aultbea Fault. The Aultbea Fault and the parallel Coigach Fault experienced repeated normal fault movement during the Precambrian, the Palaeozoic and the Mesozoic (Stewart, 1993).

\section{Glacial geomorphology of the Ullapool area}

Evidence for glaciation is abundant in the North West Highlands. Much of the area has been highly scoured and streamlined by the passage of Pleistocene ice sheets. The most recent episode of intense erosion dates from the Late Devensian period (15-30 ka BP) when the area was overwhelmed by an ice sheet flowing broadly from east to west. According to McCarroll et al. (1995) and Ballantyne et al. (1998) the surface of the last ice sheet at the glacial maximum is thought to have been around $550 \mathrm{~m}$ OD on the eastern face of Ben Mòr Coigach, falling gently to $450 \mathrm{~m}$ OD in the west. This work is currently being re-appraised, but in the light of new evidence from the wider area these values are now seen as minimum ice sheet altitudes (Ballantyne and Hall, 2008). Given that even the summits of the mountains are likely to have been covered by ice during the last glacial maximum, the present-day landscape probably reflects 
the relative degree of glacial erosion on the topography over several glacial cycles, rather than its presence or absence (Bradwell et al., 2008a).

The summits of the highest mountains in the Ullapool area, such as An Teallach and Beinn Dearg, are 'periglacial enclaves'. They were probably overridden by the last ice-sheet at its maximum extent, as erratics at 900 m OD testify (although some authors propose that these summits were not ice-covered - see Stone et al.,1998), but downstream of the mountain massifs - in the 'pressure shadow' caused by these vast bedrock obstacles - glacial erosion would have been negligible. Blockfields, tors, patterned ground, and other periglacial phenomena on the western side of An Teallach (Ballantyne, 1993) may be long-lived, relict landforms that have not been subsequently obliterated by ice sheet erosion. Similar features occur above $\sim 500 \mathrm{~m}$ on Ben Mòr Coigach, Cùl Beag and Stac Pollaidh and above 700 m on the Beinn Dearg range. The plateau surface of the Beinn Dearg range exhibits a number of preserved landscape features, such as the sinuous v-shaped valley of Allt a' Chrom-uillt to the east of Beinn Dearg (Figure 2). Its meandering trend and high elevation (600 - $800 \mathrm{~m}$ OD) would suggest that its origin is pre-glacial. Such features demonstrate limited glacial erosion at higher elevations, despite the fact that they lie beneath the reconstructed surfaces of Ballantyne et al. (1998) for the Late Devensian ice sheet. At the peak of the last Devensian glaciation, westerly ice sheet flow was focused through the low-altitude ground between the Assynt and Beinn Dearg ranges to feed a grounded, marine-terminating ice stream in the Minch (Stoker and Bradwell, 2005). The strongly streamlined terrain to the north of Glen Achall (Figure 3) is likely to be a result of focused subglacial abrasion, possibly aided by action of pressurised subglacial meltwater during phases of enhanced ice stream activity (Bradwell, 2005; Bradwell et al., 2008a). 
The main products of glacial deposition are till and morainic debris. These deposits are abundant in the eastern part of the area, but to the west, areas of till are few and far between and thick till sequences are rare. However, conspicuous deposits are found immediately west of the main mountain massifs of Ben Mòr Coigach, An Teallach and Beinn a' Chaisgein, on Cailleach Head, and on the northern side of Little Loch Broom; narrow ribbons of till are seen immediately ‘downstream’ of individual peaks such as Cùl Beag and Stac Pollaidh. The occurrence of these glacial deposits or 'till tails', in the lee of major topographic obstacles, clearly demonstrates the optimum setting for till deposition and preservation in an area of otherwise widespread glacial erosion (Bradwell et al., 2008b).

Ice sheet deglaciation in the area is documented by sequences of broad, recessional moraines. Many of these can be traced back towards an accumulation centre in the Beinn Dearg range, which survived into, and possibly throughout, Greenland Interstadial 1 (Windermere Interstadial) (Bradwell et al., 2008c). With approximately $150 \mathrm{~km}^{2}$ of surface area lying above $600 \mathrm{~m} \mathrm{OD}$, the ice cover on the Beinn Dearg massif was well placed to survive rises in equilibrium line altitudes (ELAs), whereas neighbouring upland areas have only sharp peaks and ridges reaching such elevations. However, well preserved recessional moraines are also found west of the Moine Thrust. Moraine ridges, mounds and boulder spreads describe the retreat of the last ice sheet across Wester Ross. They are particularly clear adjacent to Loch Lurgainn; around Achiltibuie in Coigach; on the southern flanks of Little Loch Broom; and further west around Gruinard Bay, Loch Ewe, and on Rubha Mòr. In many cases, these form merely the onshore extent of a well-preserved suite of moraines found across the seabed in the Summer Isles region (Stoker et al., 2006). Most of these moraines, recently dated using cosmogenic isotope analysis, formed between 13 and 
14,000 years ago (Bradwell et al., 2008c). Ongoing work is seeking to definitively tie these offshore moraines to their counterparts onshore, and to unravel the detailed deglacial dynamics of this fascinating area.

The numerous corries and valleys radiating outwards from the Beinn Dearg massif have been proposed as hosting individual glaciers during subsequent Greenland Stadial 1 (Loch Lomond Stadial) (Sissons, 1977). However, more recent work suggests that a larger, coherent ice cap or ice field with outlet glaciers was more likely (Reed, 1988; Ballantyne, 1997; Finlayson and Bradwell, 2007). A prominent, multicrested moraine ridge beyond Loch a' Gharbhrain (SE corner of Figure 1) may mark the limit of a glacier readvance at this stage.

\section{Influence of bedrock on the glacial features}

The landscape in areas of Lewisian gneiss to the west of the Moine Thrust is rough, inhospitable, almost other-worldly, ground. This classic ‘cnoc-and-lochan' scenery (Rea and Evans, 1996) is characterised by a myriad of small bedrock hills dotted with irregular-shaped lochs; till cover is rare in these areas. Many of these gnarled outcrops of Lewisian gneiss are smooth on their eastern slopes and steeper and jagged on their western slopes. These distinctive roche moutonnée forms are usually taken as primary indicators of abrasion beneath a mobile ice sheet. Indeed, if one looks in the direction of ice flow (i.e. to the west) one sees only smoothed rock faces, whilst looking in the opposite direction one sees, in stark contrast, rough craggy outcrops. This ground has clearly been glacially modified, but it is difficult to quantify how much of the topography can be attributed solely to glacial erosion during the Pleistocene, and how much is related to earlier non-glacial erosion focused on zones 
of weakness in the bedrock. However, it is notable that the relatively low-lying ground immediately north of Stac Pollaidh has relatively streamlined landforms, whereas around Gruinard Bay the landscape forms are more chaotic, possess greater relief, and lack a directional preference. The cnoc-and-lochan topography may be more streamlined in areas where the ice sheet flowed faster. Interestingly, the cnocand-lochan landscape is well-developed on the low ground close to Gruinard Bay, but more poorly developed on the higher ground of Fisherfield Forest. The relative degree of glacial modification on Lewisian terrain is a much understudied topic - one which clearly merits further investigation.

A great thickness of Torridon Group rocks unconformably overlies the Lewisian basement to the west of the Moine Thrust. In places, these rocks have been eroded away to form conspicuous isolated mountains, or inselbergs, such as Stac Pollaidh and Cùl Beag. The great massifs of Ben Mòr Coigach and An Teallach are almost exclusively composed of Torridon Group sandstone; their lower flanks have been glacially sculpted to form streamlined terraces which pick out the thick bedding.

Some areas of Torridon Group rocks form lower-lying terrain, the best example being on the peninsula of Rubha Mòr, where the strata strike NNE - SSW and form a series of low ridges. It is likely that this landscape was subjected to glacial scouring, as described by Gordon (1981) on similar rocks near Kyle of Lochalsh, with topographic development being controlled by the bedding in the exposed sandstones. The area to the south-east of Ben Mòr Coigach is also low-lying and glacially scoured, but here a set of ENE - WSW fractures which cuts across the strike of the strata partly controlled the landform development under glacial erosion. Areas of till cover on the Torridon Group rocks chiefly occur in the lee (to the west) of the major mountain massifs, as described above. 
The Moine Thrust marks a significant change in landscape character. In general, terrain to the east of the Moine Thrust has a much smoother appearance than that to the west - a characteristic partly explained by greater thickness and extent of glacial deposits on the rocks of the Moine Supergroup. The high altitude massifs of Beinn Dearg and the Fannichs are surrounded by lower altitude terrain characterised by broad, commonly low-relief valleys, although deeper valleys include the prominent NNW trending Loch Broom and the WNW trending Glen Achall. These deep valleys have most likely been deepened through successive glaciations. Within the lowerrelief area to the north of Beinn Dearg, a number of bedrock-controlled valleys trend obliquely to the main east-west ice sheet flow path. Aligned as such, these valleys provided enclaves protected from glacial erosion, and consequently host thick successions of preserved sediment (Figure 4). Such sequences may represent more than one glacial cycle and are the focus of ongoing research.

A well-defined set of east-west trending, linear megagrooves are a striking feature north of Glen Achall, clearly visible on the DSM (Figure 1). These east-west linear features are carved into bedrock and consist of parabolic, V-shaped or asymmetrical, bench-like grooves, typically between 5-15 m deep (Bradwell et al. 2008a). These very elongate features have been interpreted as the 'footprint' of a palaeo ice stream (Bradwell \& Stoker 2005; Bradwell et al. 2008a). The megagrooves are best developed where the ice flow was sub-parallel to the local strike of the bedding/foliation in the Morar Group psammite (Krabbendam et al., 2008b). 


\section{Landscape expression of faults and fractures}

Major geological structures such as faults and fractures, many of which have been reactivated many times through geological history (Beacom et al., 2001; Butler et al., 2007; Krabbendam and Leslie, in press), also exert a control on the landscape. Some of the deep, steep-sided troughs in the area, such as Loch Maree and Loch Broom, fall along lines of pre-existing geological weakness such as major faults or fractures, and glacial erosion over several glaciations has clearly served to increase the topographic relief of the area dramatically.

A number of smaller-scale, linear landscape features can also be easily seen on the DSM. These include a number of sharp, linear grooves and valleys, including a NESW trending set east of Ullapool which are cut in Moine psammite, and a NNW-SSE set to the south and south-east of Gruinard Bay, cut in Lewisian Gneiss. These grooves are clearly related to faults and fractures. Fieldwork has shown that whilst some of these faults have clear displacement, others have not and would be better described as mega-joints. Their expression in the landscape as very narrow valleys suggests that the grooves were mainly excavated by water as opposed to ice. A number of the valleys are likely to have functioned as meltwater channels during deglaciation.

A much larger feature accompanies the NE-SW trending Loch an Daimh Fault (Figure 2). A prominent damage zone of cataclasite and fractured rock occurs at the southwestern end of Loch an Daimh, and displacement of earlier faults suggests a leftlateral component of movement of about $1 \mathrm{~km}$. Part of the fault has clearly been scoured out by ice, forming the trough containing Loch an Daimh. Curiously, the south-western end of the Loch an Daimh fault lines up with the Dundonnell Culmination (see Elliott \& Johnson, 1980 for a detailed description) in the Moine 
Thrust Zone, although any potential control by the Loch an Daimh Fault (in the hangingwall of the Moine Thrust) on a thrust culmination is not easy to envisage.

A curious feature of this area, and indeed virtually the whole of the North West Highlands, is the poor topographic expression of the Moine Thrust. Whilst this structure is easily mapped by traditional fieldwork on the ground, it cannot be easily discerned on the DSM. In the area around An Teallach, ridges and valleys appear to be more strongly controlled by the bedrock strata rather than by the Moine Thrust itself. A similar situation occurs farther north, where the River Runie follows the base-Cambrian unconformity, whilst the Moine Thrust is situated, without any clear topographic expression, on the hillslopes farther east. The most likely explanation of this poor topographic expression of the Moine Thrust is that it was situated at right angles, rather than sub-parallel, to ice flow during the Pleistocene glaciations.

\section{Conclusions}

It is clear that, in the Ullapool area, there is a strong control of bedrock lithology and bedrock structure on the landscape. The differing structures in the bedrock have been exploited by glacial erosion during successive Pleistocene glaciations, and in some cases also appear to have controlled glacial deposition. In particular, it is notable that the Moine Thrust itself does not have a strong topographic expression, yet the lithologies to the east and west of the thrust have reacted in very different ways to glaciation, producing contrasting landscapes. These different types of landscapes can be studied using digital surface models in conjunction with field studies, to highlight the interplay between geology and geomorphology. 


\section{Acknowledgements}

Jon Merritt is thanked for constructive comments on an earlier version of this manuscript. This paper is published by permission of the Executive Director of the British Geological Survey.

\section{References}

Ballantyne, C K. 1993. An Teallach. In: Gordon, J E, and Sutherland, D G (ed.) Quaternary of Scotland. (London, Chapman and Hall).

Ballantyne, C K. 1997. Periglacial trimlines in the Scottish Highlands. Quaternary International, Vol. 38-39, 119-136.

Ballantyne, C K, and Hall, A M. 2008. The altitude of the last ice sheet in Caithness and east Sutherland, northern Scotland. Scottish Journal of Geology, Vol. 44, 169181.

Ballantyne, C K, McCarroll, D, Nesje, A, Dahl, S O, and Stone, J O. 1998. The last ice sheet in North-West Scotland; reconstruction and implications. Quaternary Science Reviews, Vol. 17, 1149-1184.

Beacom, L E, Holdsworth, R E, McCaffrey, K J W, and Anderson, T B. 2001. A quantitative study of the influence of pre-existing compositional and fabric heterogeneities upon fracture-zone development during basement reactivation. In: Holdsworth, R E, Strachan, R A, Macgloughlin, J F, and Knipe, R J (eds.) The nature and significance of fault zone weakening. Special Publication of the Geological Society of London Vol. 186.

BradWell, T. 2005. Bedrock Megagrooves in Assynt, NW Scotland. Geomorphology, Vol. 65, 195-204.

Bradwell, T, Fabel, D, Stoker, M S, Mathers, H, McHargue, L, and Howe, J. 
2008c. Ice caps existed throughout the Lateglacial Interstadial in northern Scotland. Journal of Quaternary Science, Vol. 23, 401-407.

Bradwell, T, Stoker, M S, and Krabbendam., M. 2008a. Megagrooves and streamlined bedrock in NW Scotland: the role of ice streams in landscape evolution. Geomorphology, Vol. 97, 135-156

Bradwell, T, Stoker, M S, Mathers, H, Finlayson, A, and Fabel, D. 2008b. Glacial sediments beneath ice streams: evidence from NW Scotland. Geophysical Research Abstracts, Vol. 10, A-05152.

British Geological Survey. 2007. Assynt. Scotland Special Sheet. Bedrock. 1:50,000 Series. (Keyworth, Nottingham: British Geological Survey.)

British Geological SurVey. 2008. Ullapool. Scotland Sheet 101E. Bedrock. 1:50,000 Series (Keyworth, Nottingham: British Geological Survey.)

Butler, R W H, Matthews, S J, and Morgan, R K. 2007. Structural evolution of the Achnashellach Culmination, southern Moine thrust belt; testing the duplex model. In: Ries, A C, Butler, R W H, and Graham, R H (eds.) Deformation of the continental crust; the legacy of Mike Coward. Special Publication of the Geological Society of London Vol. 272

ELliotT, D, and Johnson, M R W. 1980. Structural evolution in the northern part of the Moine thrust belt, NW Scotland. Transactions of the Royal Society of Edinburgh: Earth Sciences, Vol. 71, 69-96.

Finlayson, A, and Bradwell, T. 2007. Evidence for Loch Lomond Stadial ice cap glaciation of the Beinn Dearg Massif. Quaternary Newsletter, Vol. 113, 10-17. Freeman, S R, Butler, R W H, Cliff, R A, and Rex, D C. 1998. Direct dating of mylonite evolution; a multi-disciplinary geochronological study from the Moine Thrust zone, NW Scotland. Journal of the Geological Society of London, Vol. 
$155,745-758$.

Geological Survey of Scotland. 1908. Inverbroom, Sheet 92. 1:63,560.

GoRDON, J E. 1981. Ice-scoured topography and its relationship to bedrock structure and ice movements in parts of Northern Scotland and west Greenland. Geografiska Annaler, Vol. 63a, 55-65.

Holdsworth, R E, Strachan, R A, and Harris, A L. 1994. Precambrian rocks in northern Scotland east of the Moine thrust: the Moine Supergroup. In: GiBBons, W, and Harris, A L (eds.) A Revised Correlation of Precambrian Rocks in the British Isles. (London: Geological Society of London)

Johnstone, G S, and Mykura, W. 1989. British Regional Geology: The Northern Highlands (4th edition). (Edinburgh: HMSO for British Geological Survey.) Kinnaird, T C, Prave, A R, Kirkland, C L, Horstwood, M, Parrish, R R, and Batchelor, R A. 2007. The late Mesoproterozoic - Early Neoproterozoic tectonostratigraphic evolution of northwest Scotland: the Torridonian revisited. Journal of the Geological Society of London, Vol. 164, 541-552.

Krabbendam, M, Bradwell, T, and Clarke, S. 2008b. Effect of bedrock structures upon formation of glacial megagrooves by Pleistocene ice streams in NW Scotland: implications for structural interpretation of remote sensing images in formerly glaciated terrains. Tectonic Studies Group Annual Meeting, La Rocheen-Ardenne, University of Leuven 52-53.

KrabBendam, M, and LesLiE, A G. in press. Lateral variations and linkages in thrust geometry: the Traligill Transverse Zone, Assynt Culmination, Moine Thrust Belt, NW Scotland. In: Law, R, Butler, R W H, Strachan, R A, and Krabbendam, M (ed.) Continental Tectonics and Mountain Building. Special Publication of the Geological Society of London 
Krabbendam, M, Prave, A P, and Cheer, D. 2008a. A fluvial origin for the Neoproterozoic Morar Group, NW Scotland; implications for Torridon - Morar group correlation and the Grenville Orogen Foreland Basin. Journal of the Geological Society of London, Vol. 165, 379-394.

McCarroll, D, Ballantyne, C K, Nesje, A, and Dahl, S O. 1995. Nunataks of the last ice sheet in Northwest Scotland. Boreas, Vol. 24, 305-323.

Park, R G, SteWARt, A D, and Wright, D T. 2002. The Hebridean terrane. In: Trewin, N H (ed.) The Geology of Scotland (4th edition). (London, The Geological Society).

PARSONS, I. 1999. Late Ordovician to mid-Silurian alkaline intrusions of the Northwest Highlands of Scotland. In: Stephenson, D, Bevins, R E, Milward, D, Highton, A J, Parsons, I, Stone, P, and Wadsworth, W J (eds.) Caledonian Igneous rocks of Great Britain. (Chapman \& Hall).

Peach, B N, Horne, J, Gunn, W, Clough, C T, Hinxman, L W, and Teall, J J H. 1907. The geological structure of the North-West Highlands of Scotland. Memoir of the Geological Survey of Great Britain.

REA, B R, and Evans, D J A. 1996. Landscapes of aerial scouring in NW Scotland. Scottish Geographical Magazine, Vol. 112, 47-50.

REED. 1988. The vertical dimensions of the last ice sheet and Late Quaternary glacial events in northern Ross-shire. Unpublished PhD Thesis, University of St Andrews.

SABINE, P A. 1953. The petrography and geological significance of the post-Cambrian minor intrusions of Assynt and the adjoining districts of north-west Scotland. Quarterly Journal of the Geological Society of London, Vol. 109, 137-171. Sissons. 1977. The Loch Lomond Readvance in the northern mainland of Scotland. 
In: Gray, J M, and Lowe, J J (eds.) Studies in the Scottish Lateglacial

Environment. (Oxford, Pergamon Press).

StewART, A D. 1993. Late Proterozoic and late Palaeozoic movement on the Coigach fault in NW Scotland. Scottish Journal of Geology, Vol. 29, 21-28.

STEWART, A D. 2002. The later Proterozoic Torridonian rocks of Scotland: their sedimentology, geochemistry and origin. Geological Society Memoir Vol. 24.

StOKER, M, and BradWELL, T. 2005. The Minch paleo-ice stream, NW sector of the British - Irish Ice Sheet. Journal of the Geological Society of London, Vol. 163, 425-428.

StOKer, M S, Long, D, Bulat, J, and Davison, S. 2006. Seismic Geomorphology and Pleistocene Ice Limits off Northwest Britain. In: KNIGHT, P G (ed.) Glacier Science and Environmental Change. (Oxford: Blackwell Science).

Stone, J O, Ballantyne, C K, and Fifield, L K. 1998. Exposure dating and validation of periglacial weathering limits, Northwest Scotland. Geology, Vol. 26, 587-590.

\section{Figure Captions}

Figure 1: NextMap hill-shaded digital surface model of the Ullapool area, with inset showing the location within Scotland.

Figure 2: Simplified geology superimposed on the NextMap image. SBT - Sgurr Beag Thrust.

Figure 3: Typical scenery north of Ullapool. Glacially streamlined Moine psammites in Rhidorroch Forest in the foreground, with Torridon Group sandstone mountains in the background. 
Figure 4: Photograph of a thick sediment sequence preserved in the Allt Poiblidh at

[NH 307 969], a valley oblique to the predominant former ice flow direction.

\section{Figures}

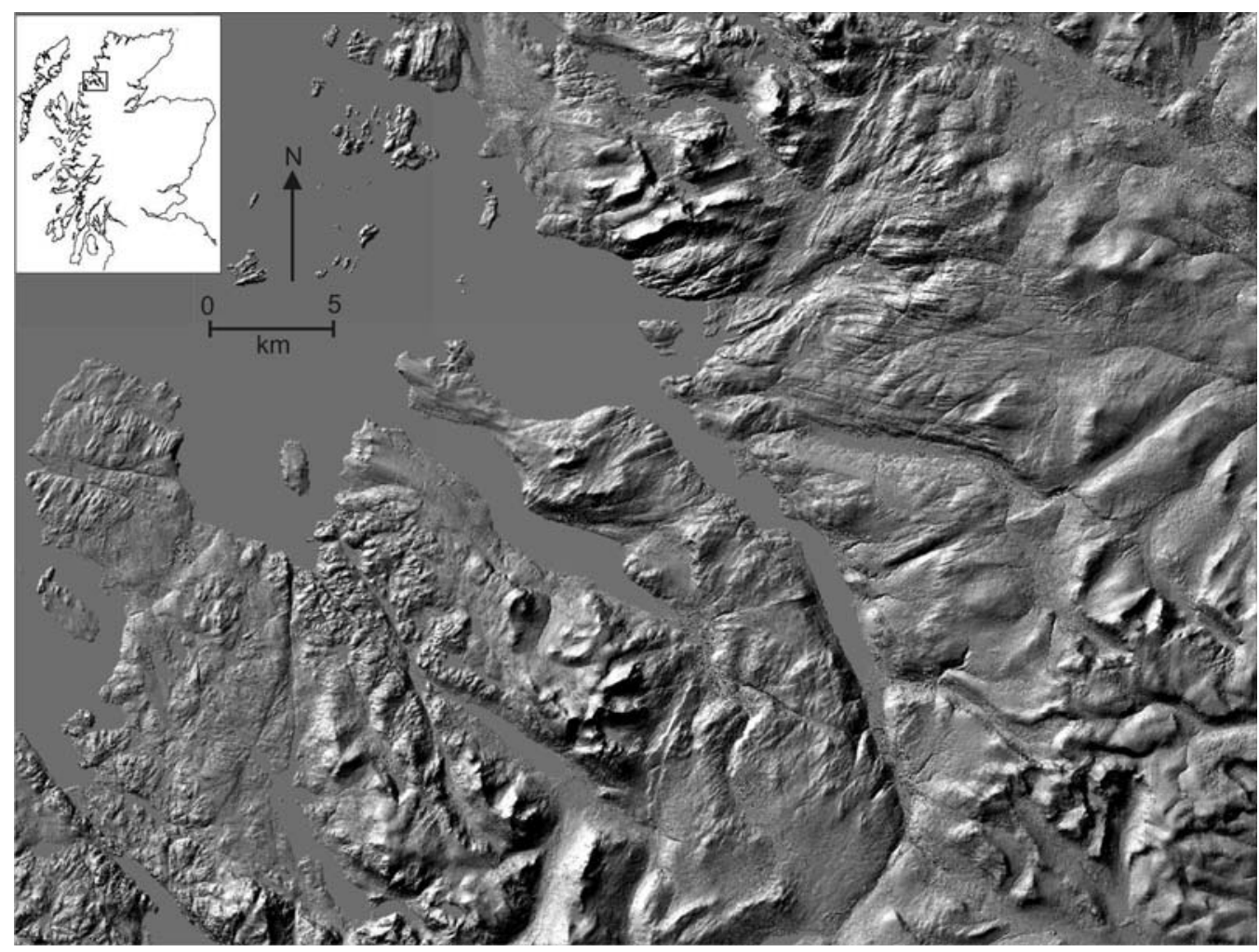

\section{Figure 1}




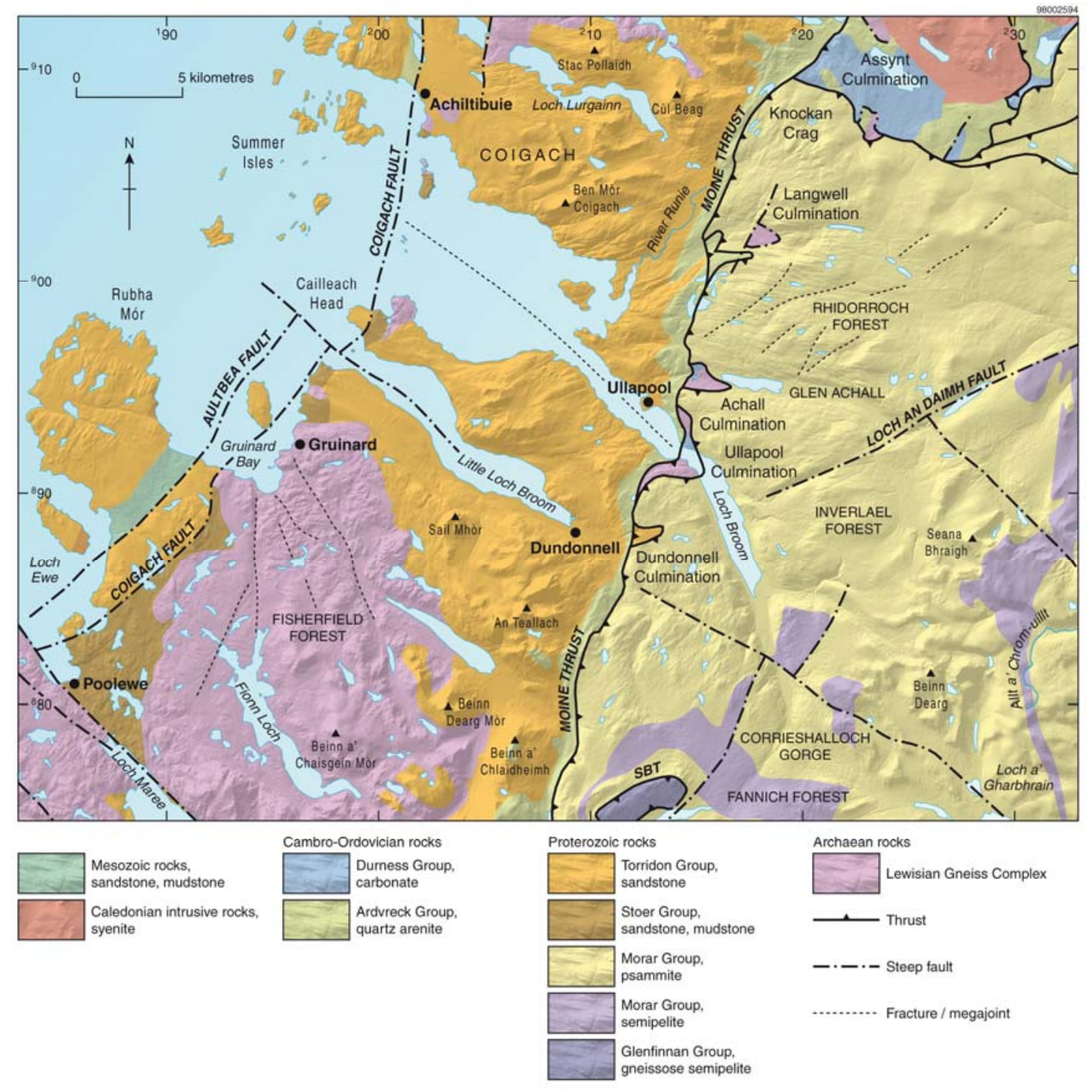

Figure 2. 


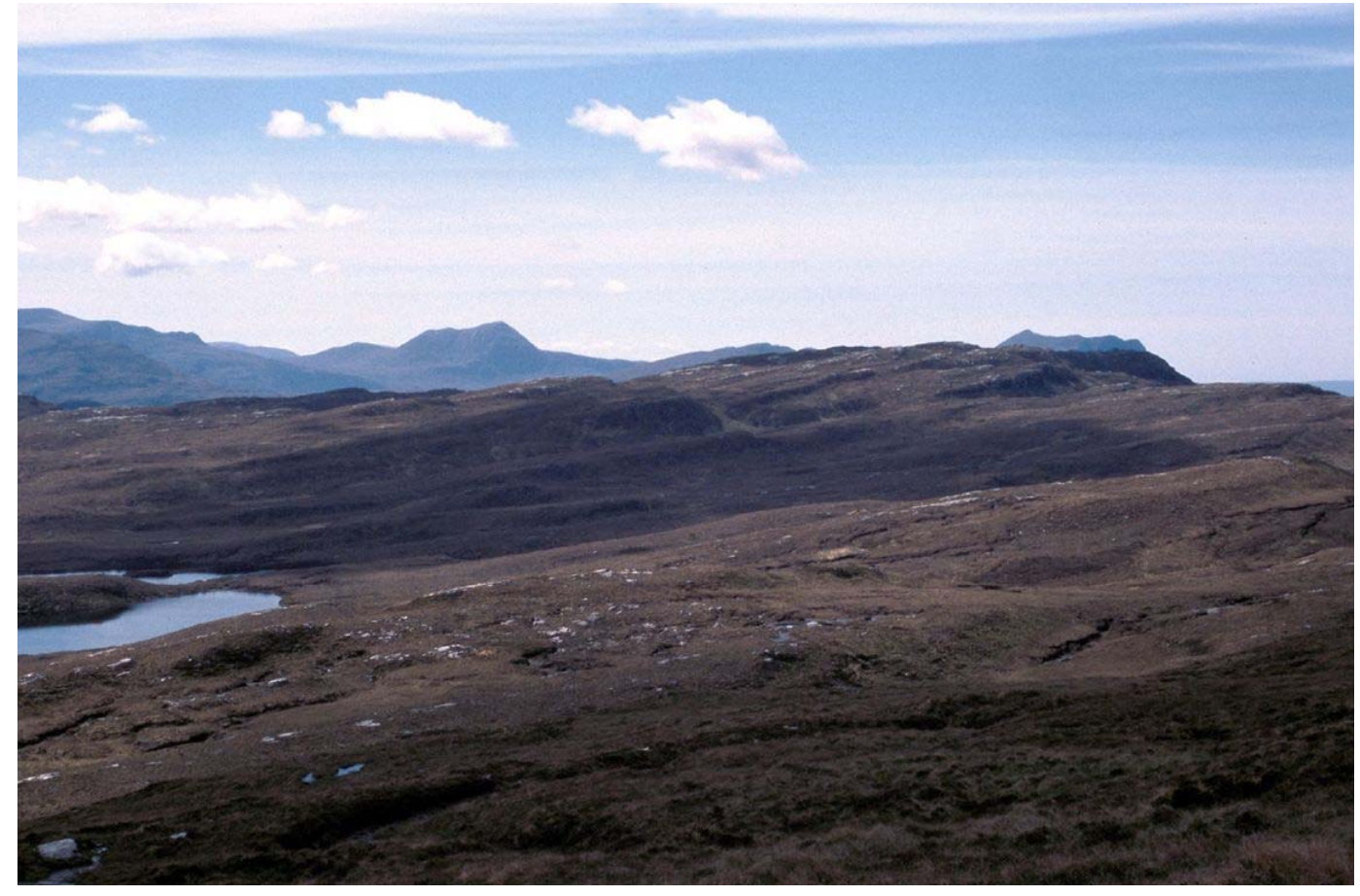

\section{Figure 3.}

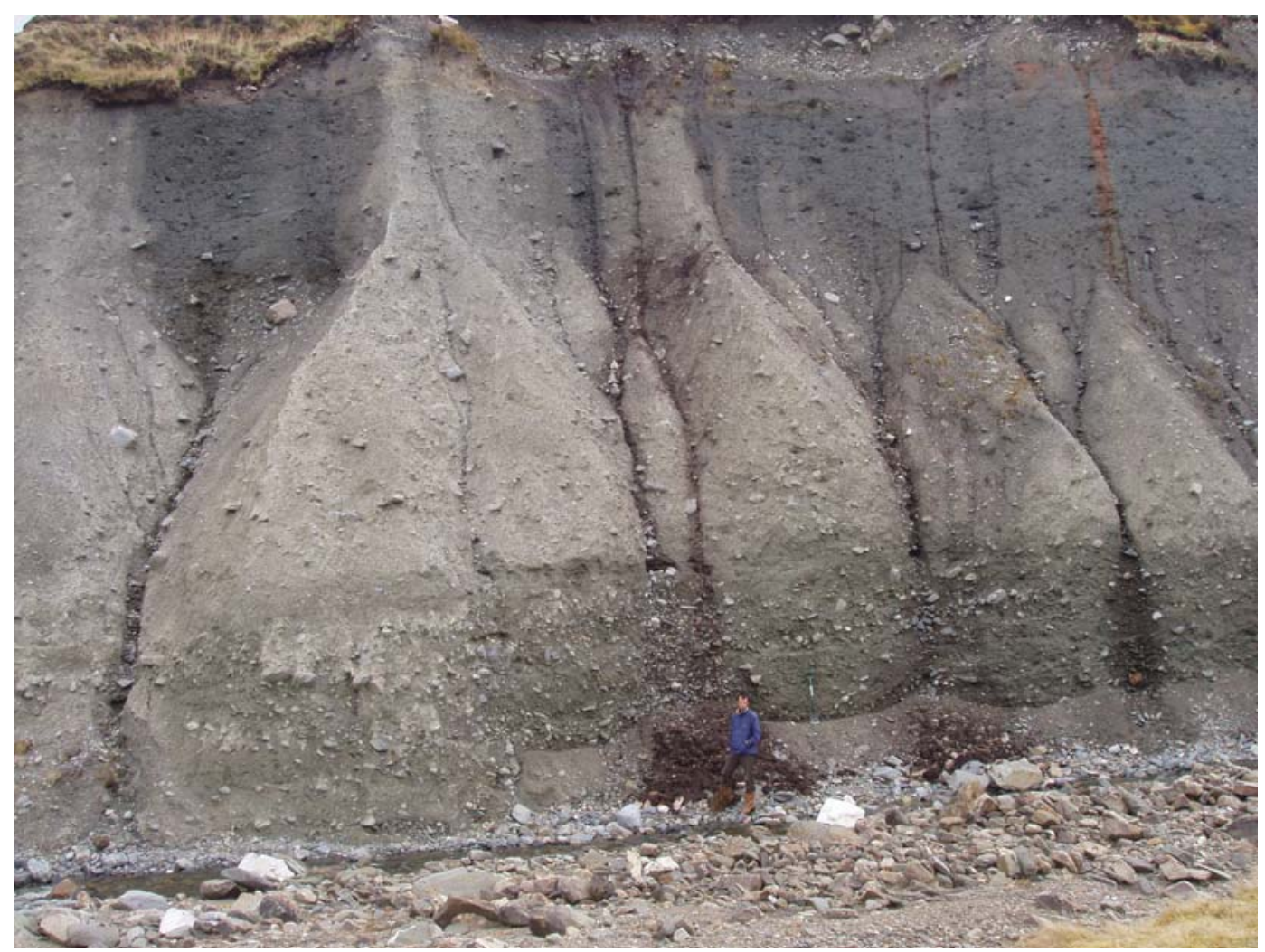

Figure 4. 